\title{
Forecasting the Impact of CCGT-CCS on the UK's Electricity Market by LCOE
}

\author{
Tianxiang Luan, Kwoklun Lo, Jianfeng Lu \\ Department of Electronic and Electrical Engineering, University of Strathclyde, Glasgow, United Kingdom \\ Email: tianxiang.luan@strath.ac.uk
}

How to cite this paper: Luan, T.X., Lo, K.L. and Lu, J.F. (2017) Forecasting the Impact of CCGT-CCS on the UK's Electricity Market by LCOE. Energy and Power Engineering, 9, 198-203. https://doi.org/10.4236/epe.2017.94B024

Received: February 24, 2017

Accepted: March 30, 2017

Published: April 6, 2017

\begin{abstract}
To achieve the target for building a low-carbon economy, the UK will have to build more low-carbon power plants to reduce carbon dioxide emissions from electricity generation. However, renewable energy is difficult to meet the increasing energy demand and keep lights on. This limitation of renewable could be solved by coal and gas-fired power station fitted with carbon capture storage (CCS) technology. CCS technology could capture up to $90 \%$ of carbon dioxide from emissions and allow fossil fuel power station to provide continuous low-carbon electricity power. This paper presents the levelised cost of electricity of CCGT with CCS and compared with renewable technology to forecast the impact of CCGT with CCS on the UK's electricity market.
\end{abstract}

\section{Keywords}

Levelised Cost of Electricity, Carbon Capture and Storage, Electricity Market

\section{Introduction}

The UK government established a binding target to reduce Greenhouse gas (GHG) emissions by at least $80 \%$ below the 1990 level by 2050 and declared that the emissions from power sector need to be close to zero by 2050 [1] [2]. The total electricity produced in 2015 is $336 \mathrm{TWh}$, and the shares of electricity generation based on primary fuel source are $24.7 \%$ from renewable, $21 \%$ from nuclear, $22 \%$ from coal and $30 \%$ from gas. To meet the climate change commitments, the UK's electricity is likely to be produced from three main low-carbon sources: renewable energy, particularly onshore and offshore wind farms; a new generation of nuclear power stations; and gas and coal-fired power station fitted with carbon capture and storage (CCS) technology [3].

Carbon capture and storage (CCS) is a technology that could remove $90 \%$ or more of the carbon dioxide emissions from coal and gas-fired power station, 
which could be used for converting fossil-fuel into low carbon power. To prevent the carbon dioxide from entering the atmosphere, the process of CCS consists of three steps: capture, transport, and storage of the emitted carbon dioxide. First, carbon dioxide will be separated and captured either by before the combustion process by pre-combustion capture, or after the combustion process by post-combustion capture or oxy-combustion capture [4]. Then, carbon dioxide will be transported by pipeline or ship and then stored carefully in selected geological rock formation which is several kilometers below the earth's surface [5]. CCS will play a vital role in efforts to limit the global warming. According to the International Energy Agency, more than 3000 CCS projects must be set up and be running by 2050 worldwide [6]. In the UK electricity system, gas and coalfired power station with CCS is an unavoidable option in order to meet the increasing energy demand and keep lights on whilst minimizing the environmental damage [7].

The acceptability of low carbon technologies is decided by the market principle the lowest generation cost will win the biggest market share [2]. Although wind and solar PV technology are become more and more mature and cheaper, CCS as a developing technology has the potential to be one of the most cost-effective technologies [8]. Currently, there are 8 operational commercial-scale CCS plants in U.S.A, Norway and Algeria [9].

This paper will estimate the levelised cost of electricity (LCOE) of the combined cycle gas turbine (CCGT) fitted with CCS technology, large scale solar PV, onshore and offshore wind by discounted cash flow method. Additionally, their LCOE will be compared and is used to forecast the CCS technology role in the UK electricity market.

\section{Levelised Costs of Electricity (LCOE) Methodology}

\subsection{Principle}

The LCOE is an important measurement for comparing the unit costs of different electricity technologies to guide discussion and decision-making [10]. The LCOE are the total costs of power generating technology per unit of electricity (MWh). The total costs of power station include:

- Pre-development

- Construction

- Infrastructure

- Fixed O\&M (operations and maintenance)

- Variable O\&M

- Insurance

- Connection and Use of System

- Fuel

- Carbon

The LCOE represents the present value of the unit cost of electricity over the lifetime of the powerstation. To account for the time-value of money, the whole costs and benefits are adjusted for inflation and discounted rate. A relatively low 
LCOE means that electricity is being produced at a low cost. There is a gap between the LCOE and the financial costs in real electricity market due to some specific uncertainties such as fuel and carbon price.

\subsection{Levelised Cost of Electricity Calculation}

The LCOE equation is an evaluation of the life-cycle energy cost and life-cycle energy production [11]. To evaluate the total cost of electricity, the streams of costs are converted to a net present value using the time value of money by discounted cash flow model. The LCOE calculation begins with Equation (1), expressing the equality between the present value of the sum of revenues on the left-hand side and the present value of the sum of costs on the right-hand side. Equation (2) is the LCOE formula, the average lifetime LCOE are the total cost of electricity technology over its total electricity production. It is not the MWhs that are discounted but instead it is the revenue from those MWh that is being discounted, as today's revenue has more value to the investor than revenue tomorrow [12].

Discounted rate, also known as the hurdle rate, is the minimum Internal Rate of Return (IRR) that a company expects to earn when investing in a project. It denotes the level of risk to invest a project, riskier projects generally have higher hurdle rate [13].

$$
\begin{aligned}
& \sum \mathrm{P}_{\mathrm{MWh}} \times \mathrm{MWh} \times(1+\mathrm{r})^{-\mathrm{t}} \\
= & \sum\left[\left(\text { Capital }_{\mathrm{t}}+\mathrm{O} \& M_{\mathrm{t}}+\text { Fuel \& } \text { Carbon }_{\mathrm{t}}\right) \times(1+\mathrm{r})^{-\mathrm{t}}\right] \\
\text { LCOE } & =\mathrm{P}_{\mathrm{MWh}} \\
& =\frac{\sum\left[\left(\text { Capital }_{\mathrm{t}}+\mathrm{O}_{\mathrm{a}} \& M_{\mathrm{t}}+\text { Fuel \& } \text { Carbon }_{\mathrm{t}}\right) \times(1+\mathrm{r})^{-\mathrm{t}}\right]}{\sum \mathrm{MWh} \times(1+\mathrm{r})^{-\mathrm{t}}}
\end{aligned}
$$

$\mathrm{P}_{\mathrm{MWh}}=$ The lifetime remuneration to the supplier for electricity;

$\mathrm{MWh}=$ The amount of electricity produced in MWh;

$(1+\mathrm{r})^{-\mathrm{t}}=$ The discount factor for year $\mathrm{t}$;

$\mathrm{O} \& M_{\mathrm{t}}=$ Operation and maintenance costs in year $\mathrm{t}$;

Fuel \& Carbon $_{\mathrm{t}}=$ Fuel and carbon costs in year t;

$\mathrm{r}=$ Discount rate;

\section{Levelised Cost of Electricity in the UK Electricity Market}

\subsection{Key Data and Assumption}

All data and assumptions are from independent consultants which are commissioned by the UK's Department of Energy \& Climate Change (DECC) [14]. Arup and Leigh [Fisher [16] [17] provide cost and technical assumptions for the renewable technologies and non-renewable technologies individually; NERA Economic Consulting [18] provide a report on hurdle rates for projects starting development from 2015. The estimate of fuel price from 2015 to 2040 is on the basis of DECC [19] 2015 fossil fuel price assumptions report. According to the UK's Department for Business, Energy and Industrial Strategy (BEIS) update, 
the carbon price is $£ 18 / \mathrm{tCO}_{2}$ from $2016 / 17$ to $2019 / 20$, and then rising to around

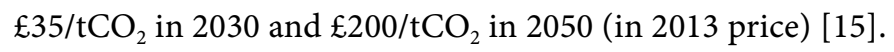

\subsection{CCGT, Wind and Solar PV}

Figure 1 shows the LCOE of CCGT H class, onshore ( $>5 \mathrm{MW}$ ), offshore wind round 3 and large scale PV projects which begin the pre-development from 2018 to 2025. LCOE of Wind and solar PV technologies is decreasing due to the reduction of construction cost and increment of average load factor. Besides, the main reason that causes LCOE of CCGT continuous rise is the increasing growth of carbon price. According to Figure 1., The LCOE of onshore technology is the lowest; the LCOE of large-scale PV will below the CCGT technology when projects start in or after 2019; And the LCOE of offshore technology is decreasing from $£ 114 / \mathrm{MWh}$ to $£ 92 / \mathrm{MWh}$ from 2018 to 2025 , which is close to the CCGT technology of $£ 90 / \mathrm{MWh}$ in 2025.

\subsection{CCGT-CCS}

Table 1 represents the LCOE of CCGT with and without CCS technology project starting in 2030, 2035 and 2040 respectively. Post and pre-combustion technology could capture $90 \%$ and $93 \%$ carbon dioxide respectively. And the rest of greenhouse gases need to be paid the carbon cost, so the increasing carbon price leads to the increase of LCOE. The LCOE of pre-combustion technology is the highest among 2030, 2035 and 2040 respectively. On the contrary, post-

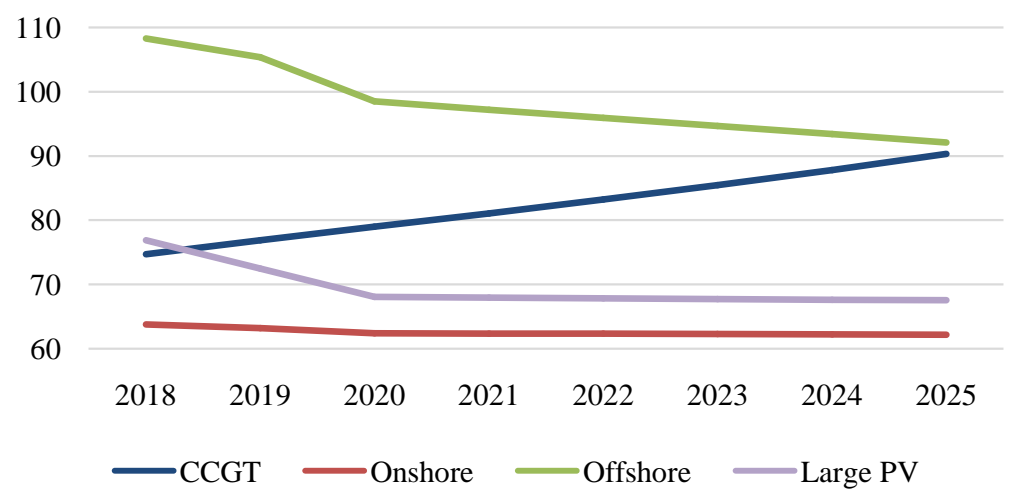

Figure 1. The LCOE of project starting from 2018 to 2025.

Table 1. The LCOE of CCGT with CCS technology commissioning in 2030, 2035 and 2040.

\begin{tabular}{cccc}
\hline \multirow{2}{*}{ Technology } & \multicolumn{3}{c}{ Levelised Cost of Electricity (f/MWh) } \\
\cline { 2 - 4 } & 2030 & 2035 & 2040 \\
\hline CCGT-post combustion & 163.6 & 164.7 & 165.2 \\
$\begin{array}{c}\text { CCGT-pre combustion } \\
\text { CCGT-oxyfuel } \\
\text { combustion }\end{array}$ & 170.1 & 171 & 171.4 \\
CCGT & 165.3 & 165.3 & 165.3 \\
\hline
\end{tabular}


combustion technology is the lowest. Moreover, oxyfuel combustion technology has the trend to be the cheapest CCS technology.

\subsection{Discussion}

According to the estimated results, CCGT with CCS is used as the main lowcarbon fossil fuel power generation technology would serve as the peaking or backup power plant in the UK's electricity market. And renewable energy would make a huge contribution to the low-carbon economy. The most interesting thing is the LCOE of CCGT without CCS is lower than that of CCGT using CCS, even though it includes the carbon cost to release emissions directly into the atmosphere. Currently, the LCOE of CCGT with CCS is not competitive enough with wind and solar PV technology. But, the CCS technology has much potential to reduce its LCOE, such as investing in large $\mathrm{CO}_{2}$ storage clusters with shared pipelines to decrease the operation cost; re-use of existing oil and gas infrastructure to reduce the construction cost; developing a subsidiary supply business to increase the revenue of power plant. If the LCOE of CCGT with CCS could be reduced to an appropriate price level, the UK government could use CCS technology to maintain secure and low carbon electricity as more intermittent renewables and inflexible nuclear come onto the grid, and does not worry about the suddenly increased household electricity bills.

\section{Conclusion}

This paper forecast the impact of CCGT with CCS technology on the UK electricity market through calculating LCOE and compared with the wind and solar PV technologies. To achieve the greenhouse gases reduction target, CCS technology will play as an important role to a low-carbon future, which allows continued use of fossil fuels whilst limiting global temperature rises. The LCOE of CCGT with CCS project commissioning from 2030 to 2040 are relative high when compared with the wind, solar PV, and CCGT. Therefore, CCGT with CCS technology in the UK is most likely to be peaking or backup power plants rather than base load power stations.

\section{References}

[1] CCC. (2012) The 2050 Target. https://www.theccc.org.uk/archive/aws/IA\&S/CCC_IAS_Tech-Rep_2050Target_Int eractive.pdf

[2] UK Government HM Revenue \& Customs. (2011) The Carbon Plan: Delivering Our Low Carbon Future.

https://www.gov.uk/government/uploads/system/uploads/attachment_data/file/476 13/3702-the-carbon-plan-delivering-our-low-carbon-future.pdf.

[3] UKERC. (2013) Low- Carbon, Resilient Scenarios for the UK Energy Systm in 2050. www.ukerc.ac.uk/asset/C617007B-00AE-455E-8AEBDF5146FBE3CB/

[4] Carbon Capture \& Storage Association. (2016) What is CCS? http://www.ccsassociation.org/what-is-ccs/

[5] Global CCS Institute. (2010) Economic and Social Benefits of CCS. 
https://www.globalccsinstitute.com/insights/authors/judith/2010/11/29/economic-a nd-social-benefits-ccs.

[6] IEA. (2012) CCS in a Global Climate Change Context. https://www.iea.org/media/workshops/2012/ccsmexico/1DennisBest.pdf.

[7] CCSa. (2016) How will CCS Help Us Tackle Climate Change? http://www.ccsassociation.org/faqs/why-do-we-need-ccs-climate-change/.

[8] DECC. (2012) CCS Roadmap: Supporting deployment of Carbon Capture and Storage in the UK.

https://www.gov.uk/government/uploads/system/uploads/attachment_data/file/483 17/4899-the-ccs-roadmap.pdf

[9] CCSa.(2016) CCS Globally. http://www.ccsassociation.org/faqs/ccs-globally/

[10] Lo, K. andLuan, T.X. (2016) Effect of Carbon Price Floor on Levelised Cost of Gas-Fired Generation Technology in the UK. World J. Eng. Technol, 4, 66-77. https://doi.org/10.4236/wjet.2016.43D009

[11] Cambell, M. (2008) The Drivers of the Levelized Cost of Electricity for Utility-Scale Photovoltaics.

https://us.sunpower.com/sites/sunpower/files/media-library/white-papers/wp-leveli zed-cost-drivers-electricity-utility-scale-photovoltaics.pdf.

[12] IEA, NEA, OECD. (2015)Projected Costs of Generating Electricity 2015. International Energy Agency, Paris.

[13] Investopedia. (2016) Hurdle Rate. http://www.investopedia.com/terms/h/hurdlerate.asp

[14] DECC. (2016) Energy generation Cost Projections Gov.uk. https://www.gov.uk/government/collections/energy-generation-cost-projections

[15] BEIS. (2016) Electricity Generation Costs. https://www.gov.uk/government/uploads/system/uploads/attachment_data/file/566 567/BEIS_Electricity_Generation_Cost_Report.pdf.

\section{Submit or recommend next manuscript to SCIRP and we will provide best service for you:}

Accepting pre-submission inquiries through Email, Facebook, LinkedIn, Twitter, etc. A wide selection of journals (inclusive of 9 subjects, more than 200 journals) Providing 24-hour high-quality service User-friendly online submission system Fair and swift peer-review system Efficient typesetting and proofreading procedure Display of the result of downloads and visits, as well as the number of cited articles Maximum dissemination of your research work

Submit your manuscript at: http://papersubmission.scirp.org/

Or contact epe@scirp.org 